\title{
Resnica v avtobiografiji \\ Sporočanje resničnega $v$ nekaterih svetovnih avtobiografijah in v Cankarjevem Mojem življenju
}

\author{
Irena Avienik Nabergoj \\ Univerza v Novi Gorici, Fakulteta za humanistiko, Vipavska 13, \\ SI-5000 Nova Gorica, irena.avsenik-nabergoj@guest.arnes.si
}

\section{SCN IV/1 [2011], 80-96}

Članek obravnava vidike izražanja resničnosti in resnice v avtobiografiji ob upoštevanju nekaterih avtobiografskih del od antike do danes in Cankarjeve avtobiografije Moje življenje. Predstavitev različnih stališč o resničnosti in resnici ponuja kriterije presojanja avtentičnosti in verodostojnosti literarnih predstavitev življenjske izkušnje in življenjskih zgodb. Tako lahko bolj jasno vidimo, kaj je skupnega in kaj je različno $\mathrm{v}$ avtobiografskem pisanju v primerjavi s pesništvom oziroma fikcijo. Poglavitni namen članka je presoja možnosti in meja sporočanja resnice o življenju z izpovednimi oblikami, ki so značilne za zvrsti avtobiografije.

This article discusses aspects of conveying truth in autobiography with respect to a variety of historic autobiographical works in comparison to Ivan Cankar's autobiography, Moje življenje ('My Life'). A discussion of different viewpoints on truth and reality provides criteria for judging the authenticity and credibility of literary presentations of life experience and life stories. In this way, it is possible to see more clearly what is common and what is different in autobiographical writing compared to poetry and fiction. The aim of the article is to assess the possibilities and limits of conveying truth about life by means of confessional forms characteristic of genres of autobiography.

Ključne besede: biografija, avtobiografija, zgodovina, resnica, Ivan Cankar

Key words: biography, autobiography, history, truth, Ivan Cankar

V literaturi vseh literarnih vrst in zvrsti od antike naprej je temeljno vprašanje resničnosti, verodostojnosti in resnice. To velja zlasti za tiste literarne vrste in zvrsti, ki izhajajo iz splošne ali osebne zgodovine. Ko poskušamo 
presojati pojma resničnosti in resnice $\mathrm{v}$ literarnih delih, ki $\mathrm{v}$ umetniških oblikah prikazujejo resničnost snovnega sveta in resnico o življenju v vseh njegovih odtenkih, je smiselno izhajati iz splošnih opredelitev teh pojmov. V novejšem obdobju so si filozofi prizadevali razviti teorije, s katerimi bi pojasnili naravo resnice in njenega nasprotja, neresnice. Pomenska širina je razvidna iz vidikov specifikacije teorij resnice: koherenčna teorija (Baruch Spinoza, Georg W. F. Hegel, Gottfried Leibniz), korespondenčna teorija (Bertrand Russel, George E. Moore), pragmatična teorija (Charles S. Pierce, John Dewey, William Jones). Ko »navadni« ljudje, ki živijo v resničnem svetu, uporabljajo izraz »zdrava pamet«, je to navadno v kontrastu z njegovim nasprotjem, nesmislom, ker je tisto, kar je proti zdravi pameti, nesmiselno. Na splošno ljudje, ki uporabljajo zdravo pamet, radi zaupajo svojim petim čutom zaznavanja in zato zaupajo opažanjem o realnosti, ki jih njihovi čuti zaznajo. Zdrava pamet kot oblika resnice se običajno upira »velikim« in očitnim paradoksom in ljudem daje zaščito pred skrajnimi absurdi (Smallwood 1995: 883-886).

Vendar formalna logika ne zmore pojasniti nekaterih vrst resnice, neresnice ali zmote, še posebej tistih, ki so povezane z moralnimi ali etičnimi vsebinami. Prizadevanje za resnico ni samo zadeva »zdrave pameti«, ampak tudi številnih drugih skritih lastnosti človeškega duha in medčloveških odnosov. Narava medčloveških odnosov in neizbežnost tesnih medsebojnih vezi sta lahko razlog, da se tudi prizadevanje denimo nekega pisatelja za resnico lahko konča vsaj z etičnim dvomom, ko je njegovo razkrivanje resnice povezano $\mathrm{z}$ zasebnostjo drugih ljudi in njihovo svobodo. Prizadevanje za resnico pa lahko vodi tudi $\mathrm{v}$ zmoto, ko resnico človek razglaša pod vplivom predsodkov, samovoljnosti ali »občutkov«. Ljudje, ki ne poznajo »dejstev«, doživljajo neko vrsto praznine ali vrzeli in zato svojo praznino ali vrzel pogosto zapolnijo z zmotami. Hotena neresnica pogosto vodi v nemoralnost in/ali neetično ravnanje. Zdi se, da so predsodki poglavitni vir hotenih neresnic, ki povzročajo veliko škode in trpljenja.

Ko poskušamo najti možnosti presojanja resničnosti in resnice na področju literature, se srečamo z življenjskimi prizori in usodami sredi kočljivih zgodovinskih okoliščin in izzivov. To dejstvo je Käte Hamburger izpostavila, ko je v svoji knjigi Resnica in estetska resnica opravila natančnejšo analizo opredelitev resnice na področju estetskih teorij. Na koncu svojega dela pravi:

V naši analizi estetskih teorij resnice smo si prizadevali pokazati, da je v njih uporabljeni pojem resnice pomensko prazen, pojem estetske resnice pa aporija; nasprotno, toda ravno s tem pa smo tudi skušali resnico »rešiti« pred njeno zlorabo na področju umetnosti in jo razumeti v njenem navsezadnje etičnem pomenu kot vodilni vrednostni pojem človeškega življenja in človeške družbe (Hamburger 2004: 139).

Käte Hamburger je na tej točki končala svojo raziskavo pojma resnice. V novejšem obdobju pa imamo nekaj prispevkov literarnih teoretikov in pisateljev, ki obravnavajo vprašanje resničnosti in resnice v literaturi. Leta 1946 je Erich Auerbach objavil svoje monumentalno delo o prikazovanju resničnosti v 
zahodni literaturi pod naslovom Mimesis. ${ }^{1} \mathrm{~V}$ tem delu avtor poglobljeno razlaga vidike resničnosti in resnice, ki jih pogrešamo v večini teorij o estetiki. Najnovejši poskus strokovne presoje izražanja resničnosti in resnice v literaturi je zbornik esejev pisateljev, ki jih je leta 2008 izdal David Lazar v knjigi Truth in Nonfiction. Dvajset pisateljev in literarnih teoretikov je prispevalo svoje ugotovitve o resnici v literarnih zvrsteh, kot so biografija, avtobiografija, spomini, dnevniki, eseji itd. Pogledi pisateljev so dragoceni tudi zato, ker svoje ocene o resnici $v$ teh vrstah literature ne sporočajo samo pod vidiki narave in namena literarne predstavitve življenjskih zgodb, temveč tudi pod vidikom narave literature kot takšne in svojih lastnih zgodb glede na odzive na njihova literarna dela, v katere vključujejo osebe iz svojega ožjega ali širšega življenjskega okolja. Ko govorimo o resnici, ki se kaže v medčloveških odnosih in v naših nazorih o temeljnih vrednotah zasebnega in družbenega življenja, se srečamo z različnimi vrstami aporij. Iskanje resnice je bistveno povezano z razponom med šibkostjo in močjo, ki ju doživlja vsak človek. Mohandas K. Gandhi v svoji avtobiografiji, ki ji je dal naslov Zgodba o mojih eksperimentih z resnico, pomenljivo opisuje svojo izkušnjo iskanja resnice:

Iskanje resnice je preprosto in težavno hkrati. Nadutemu človeku se bo nemara zdelo povsem nemogoče, nedolžnemu otroku pa čisto mogoče. Iskalec resnice mora biti ponižnejši od prahu. Svet tepta prah pod seboj, iskalec resnice pa se mora tako zelo ponižati, da ga celo prah lahko potepta. Šele tedaj, nič prej, se nam odstre uvid v resnico (Gandhi 2010: 18).

\section{Skupne in posebne lastnosti resnice v pesništvu, biografiji in avtobiografiji}

Od grške antike naprej so kriterije resničnosti in resnice v literaturi presojali pod različnimi vidiki. Platon se o tem sprašuje v deseti knjigi Države (Politeía) in jasno izraža pomislek do umetnosti posnemanja, zlasti pesništva. Meni, da slikar, čigar delo je samo posnetek narave, ne more izpovedati ničesar »bistvenega«, ničesar pravi biti ustreznega. Zato se vda čutni predstavi, če na primer naslika stol perspektivično. Po Platonu

enako velja za pesnika, če posnema ljudi v vsakdanjem življenju pri njihovih opravilih in kretnjah. Pesništvo, ki oblikuje bitja s pogledom na bistvo življenja, na ideje, torej bitja, ki iščejo iz vsakdanjosti pot v večno veljavni svet, je za Platona pravo pesništvo, seveda ob upoštevanju etične življenjske norme kot vodila (Platon 1995: 404, Košarjeva opomba).

V deseti knjigi (6. razdelek) Platon meni: »Kar pesnik prikazuje, so posnetki, zelo oddaljeni od resnice« (Platon 1995: 305). Vidike resničnosti v zgodovinopisju in literaturi pa označi Aristotel na začetku devete knjige svoje Poetike:

${ }^{1}$ Izbor besede za glavni naslov je pomenljiv, saj je posnemanje (mimesis) resničnosti od grške antike naprej osrednja tema, ko gre za načine izražanja v umetnosti na splošno in posebej v literaturi. 
Pesnikova naloga ni pripovedovati, kaj se je v resnici zgodilo, temveč kaj bi se bilo lahko zgodilo, se pravi, kaj bi se po zakonih verjetnosti in nujnosti utegnilo zgoditi. Zato tudi razlika med zgodovinarjem in pesnikom ni $\mathrm{v}$ tem, da eden piše $\mathrm{v}$ prozi, drugi v verzih (saj bi tudi Herodotovo zgodovino lahko kdo prelil v verze, pa bi ne bila nič manj zgodovina kot $\mathrm{v}$ prozi), razlika je marveč $\mathrm{v}$ tem, da eden opisuje, kar se je $\mathrm{v}$ resnici zgodilo, drugi pa, kar bi se bilo lahko zgodilo. Zato je poezija nekaj, kar je bliže filozofiji in pomembnejše kot zgodovinopisje: poezija govori bolj o splošnem, zgodovinopisje o posameznostih (Aristoteles 2005: 96).

Iz te izjemno vplivne opredelitve razlike med pesništvom in zgodovinopisjem ni razvidno, katere vidike resničnosti ima Aristotel v mislih, ko govori o pesnikovem prikazovanju resničnosti. O tem lahko domnevamo predvsem ob upoštevanju njegovega izhodišča v pojmu posnemanja (mimesis), ki ga uporablja in razlaga na več mestih svoje Poetike. Aristotel govori o posnemanju dejanj in značajev, torej o prikazu brez odpiranja moralnih dilem glede vesti in osebne nedolžnosti oziroma krivde junakov. Pesniku celo priporoča svobodo glede prirejanja značajev (15. poglavje, 1454 b 10). ${ }^{2}$

$\mathrm{V}$ 16. stoletju je bilo v presojanju umetnosti aktualno vprašanje definicije narave, razumevanja načina posnemanja $v$ umetnosti, objekta in smotra poetične reprezentacije v odnosu do resničnosti. Na to se je odzval Sir Philip Sidney (1554-1586) z delom The Defense of Poetry (1580-1581), ki se opira na Aristotelovo Poetiko in Horacijevo delo Ars Poetica. Zavrnil je stališča, ki ne ustrezajo naravi poezije. Sidney poeziji prisoja večjo prepričevalno moč v sporočanju resnice kakor filozofiji in zgodovini. V svoji obravnavi številnih literarnih zvrsti, kot so pastorala, elegija, satira, komedija, tragedija in ep, zavrača tezo, da je pesnik »lažnivec«, in poudarja, da poezija moralno sporočilo posreduje s sredstvi umetnosti, ki posredujejo tudi občutek veselja. Kriterij resničnosti je v prvi vrsti sporočilo v razmerju do naravnih danosti in etične kakovosti oseb, ki jih literarna dela obravnavajo. Ta kriterij mu omogoča stopnjevanje skladnosti $\mathrm{z}$ resničnostjo in resnico $\mathrm{v}$ posnemanju in izražanju stvarnosti $\mathrm{v}$ razponu od najbolj vzvišenih namigov na Boga in njegovo pravičnost v Svetem pismu, prek bogov in polbogov v grško-rimski kulturi, do najbolj preprostih resnic v različnih vrstah mitov, ki opisujejo naravo in človeške značaje. Ker so miti literarne stvaritve in prikazujejo najrazličnejše vidike vrednot v zvezi z bogovi in ljudmi, brez dvoma s svojimi umetniškimi prezentacijami sporočajo resnico na privlačen način. S svojo celostno podobo resničnosti in s slikovitostjo resničnost in resnico posredujejo bistveno bolj razumljivo kakor filozofija, zgodovina in pravo, ki imajo vsaka svoj specifični namen udejstvovanja. ${ }^{3}$

${ }^{2}$ Sodobno zgodovinopisje postavlja pod vprašaj vprašanje resnice oz. trditev, da zgodovinar »opisuje, kar se je v resnici zgodilo«. Zdi se, da je vloga zgodovinarja blizu vlogi pesnika. Gl. Luthar 2008: 178-188.

${ }^{3}$ Za predstavitev Philipa Sidneyja in celotno besedilo njegovega dela The Defence of Poetry gl. Vincent B. Leitch (ur.), The Norton Anthology of Theory and Criticism. New York / London: W. W. Norton \& Company, 2010, 251-283. 
Na začetku svojega dela The Defence of Poetry Sidney navaja prvotno latinsko oznako za pesniško vrsto literarnih del: pesnik je bil vates 'prerok, vedež', vaticinium 'prerokba'. Že izraz sam pove, da so pesniki veljali za posrednike božjih sporočil. Utemeljenost tega poimenovanja vidi predvsem v »božjih spevih« Davidovih Psalmov. Gre za nebeško poezijo, ki opeva »neizrekljivo in večno lepoto, ki jo vidijo oči razuma, razsvetljenega z vero« (Leitch 2010: 256). Grški pojem »poet « prihaja iz glagola poieîn 'narediti, ustvariti' v najodličnejšem pomenu besede. Tako kot vse znanosti ima tudi umetnost stvaritve narave za svoj poglavitni objekt, zato se v osnovi ne morejo motiti. Pesnik pa poustvarja naravo, pa tudi oblike bitij, ki jih v naravi nikoli ni bilo: »junake, polbogove, kiklope, privide, furije in podobno« (Leitch 2010: 257). Pesnik v prezentaciji primerov prave ljubezni, stanovitnega prijateljstva, junaških in odličnih mož ustvarja na temelju ideje, ki presega vidno naravo. Na temelju grško-rimske razlage, da je umetnost posnemanje (mímesis), Sidney poudari možnost metaforične izrabe narave $\mathrm{z}$ dvema ciljema: pouk in zadovoljstvo.

Vzvišen moralni cilj pesništva Sidneyju daje podlago za to, da vlogo pesnika povzdigne nad vlogo filozofa moralista, zgodovinarja in pravnika. Filozof abstraktno razglablja o kreposti, zgodovinar resnico išče v posameznih dejstvih, pravnik o dobrem in slabem sodi pod prisilo, pesnik pa vodi $\mathrm{v}$ uresničevanje vrline s tem, da zajame celoto živete resničnosti; "pesnik je dejansko pravi ljudski filozof« (Leitch 2010: 263). V drugi polovici prispevka Sidney zavrača kritiko pesnikov, češ da njihov način posnemanja resničnosti ne ustreza resnici. Temeljni argument je, da pesnik ničesar ne trdi, zato nikoli ne laže. Lagati pomeni trditi, da je resnično nekaj, kar je napačno. Drugi umetniki, posebno pa zgodovinarji, se s svojimi trditvami o številnih rečeh v meglenem znanju človeštva težko izognejo številnim lažem. Toda pesnik ne more lagati, ker nikoli ničesar ne trdi in bralca ne sili v to, da njegovo pisanje sprejme kot resnično. Zato ne laže, tudi ko pripoveduje stvari, ki niso resnične. Pesnikovi karakterji in dejanja so le slike tega, kar bi moralo biti, ne pa zgodbe o tem, kaj je bilo, zato lahko posredujejo resnico tudi v literarni fikciji.

Samuel Johnson (1709-1784) je Sidneyjeve poglede potrdil s svojo razlago bistva fikcije in umetniške odličnosti Shakespearovih zgodovinskih dram. Po njegovi razlagi dela fikcije prikazujejo življenje v njegovem »resničnem stanju« (true state), resnica pa se ne kaže samo v posnemanju narave po njenem videzu, temveč predvsem po ustreznem prikazu moralnega stanja glavnih osebnosti, ki nastopajo v literarnih delih. Ne strinja se z nevtralnim stališčem glede vloge etike; po njegovem je treba nenehno zabičevati, »da je krepost najvišji dokaz razumevanja in edina trdna osnova veličine, in da je pokvarjenost naravna posledica ozkega mišljenja; da se začne v napaki in konča v sramoti« (Leitch 2010: 337-371). V svojem predgovoru k izdaji Shakespearovih del leta 1765 pa Johnson sporoča svoje ugotovitve, kako je Shakespearu uspelo v svojih delih, ki so v bistvu literarne fikcije, čeprav pogosto temeljijo na zgodovinskih dogodkih, prikazati resničnost oziroma resnico. Uspelo mu je ustvariti zvesto zrcalo vedenja in življenja, človeško naravo skladno z delovanjem v resnični nujnosti, svoja čustva je prilagodil resničnemu življenju, njegova opažanja vsebujejo »splošno 
in prevladujočo resnico«, njegovi značaji so naravni in dosledni v ravnanju, $\mathrm{v}$ svojih delih je ohranil enotnost dejanja. Glede na te bistvene lastnosti kakovosti literarnega dela Johnson različnih Shakespearovih pomanjkljivosti, zlasti pogoste neusklajenosti v prikazu zaporedja in izbora zgodovinskih dogodkov v njegovih delih, nima za usodne hibe (Leitch 2010: 373-386).

Pisateljica Judith Ortiz Cofer, profesorica angleščine in ustvarjalnega pisanja na Univerzi v Giorgi, je sprejela moto Philipa Sidneyja »Poglej v svoje srce in piši (Look into Thy Heart and Write) « in za knjigo Truth in Nonfiction pripravila prepričljiv prispevek o vidikih resnice v poeziji in avtobiografiji. ${ }^{4}$ Vloga pesnika je, da $\mathrm{v}$ jezik grobe človeške izkušnje postavi tisto, kar je Czeslaw Milosz imenoval »edina domovina«; $v$ tem je resničnost poezije:

Pesmi so vedno resnične. Lahko čutite njihovo resničnost; $v$ vas odmeva kot glas čistega kristala. In ko slišite dobre pesmi, vprašanje, ali se je to v resnici zgodilo?, ki ga pogosto slišimo od neizkušenih bralcev, nima odmeva, ker to ni pomembno. Resnica poezije je kakor kvantna fizika. Sprejeti jo moramo, tudi če je ne dojemamo prav dobro. Es la pura verdad (Lazar 2008: 27).

Avtorica poudarja, da si v pisanju o življenjskih zgodbah izrecno prizadeva za točnost v navajanju zgodovinskih dejstev, a se zaveda, da je »resnica umetnosti različna od zgodovinskega dejstva«. Ko je svoje sorodnike posamično spraševala o istih dogodkih, so se zgodbe »dramatično « razlikovale druga od druge. Narava spomina je takšna, da $\mathrm{v}$ življenjskem toku nastajajo različne verzije istih dogodkov. Tako nastane opredelitev resnice v pisanju iz spomina, ki jo sporoča Virginia Woolf: to so osebni vtisi, sledovi, ki te vodijo nazaj do tvojih trenutkov bivanja. Poskusi, da razišče resnico o svojem življenju in jo izrazi v umetniški obliki, jo silijo, da »najde univerzalno v posameznem« in pri tem ugotavlja, da smo v neki točki dejansko vsi tujci v svojem domačem okolju (Lazar 2008: 29-30).

Definicija o avtobiografski pripovedi ali pripovedi o življenju bolj, kot da bi določala pravila kot žanra ali oblike, razume to pripovedovanje kot zgodovinsko umeščeno prakso samopredstavljanja. $V$ takšnih besedilih pripovedovalci selektivno predstavijo svojo življenjsko zgodbo skozi osebno pripovedovanje zgodbe. Umeščeni v specifične čase in prostore so hkrati v dialogu z osebnimi procesi in arhivi spomina. Smith in Watson zaradi bogate in raznolike zgodovine samoreferencialnih modelov razlikujeta med nizom terminov - pripoved o življenju (life writing), življenjska zgodba (life narrative) in avtobiografija. Pripoved o življenju je splošni izraz za raznovrstno pisanje, ki zajema življenje kot svoj subjekt.

Takšno pisanje je lahko biografsko, romanopisno, zgodovinsko ali eksplicitno samoreferencialno do pisca. Življenjsko zgodbo razumemo kot nekoliko ožji termin, ki vključuje več vrst samoreferencialnega pisanja, vključno z avtobiografijo (Smith and Watson 2001: 3).

${ }^{4}$ Gl. La Verdad: Notes on the Writing of Silent Dancing, partial Remembrance of a Puerto Rican Childhood (a Memoir in Prose and Poetry). V. David Lazar, ur. Truth in Nonfiction, 26-30. 
$\mathrm{V}$ človeški naravi vzporedno s težnjo po resnici deluje težnja po iskanju zgodovinskih »dejstev«, zato ni samoumevno, da bralec avtobiografske pripovedi dovolj zavestno razlikuje med »estetsko« in »zgodovinsko« resnico. Pisci avtobiografij so morali vsak na svoj način najti način usklajevanja teh dveh postavk. Prej kot »dejstvo« ponujajo subjektivno »resnico« (Smith in Watson 2001: 10). Več vprašanj se odpira, ko poskušamo ugotoviti, kaj je specifično v izražanju resnice $\mathrm{v}$ avtobiografskem pisanju v primerjavi z biografijo, romanom ali zgodovinskim pisanjem:

Kakšen je položaj resnice v avtobiografskem razkritju? Kako vemo, ali in kdaj pripovedovalec govori resnico ali laže? In kakšno razliko bi to razlikovanje povzročilo? /.../ Kaj je tisto, kar pričakujemo, da nam bo pripovedovalec o življenju povedal resničnega? Ali pričakujemo zvestobo do dejstev, do pripovedovalčevega življenjepisa, do njegovih izkušenj, do samega sebe, do zgodovinskega trenutka, do družbene skupnosti, do prevladujočih prepričanj o različnih identitetah, do norm avtobiografije kot literarnega žanra samega na sebi? In resnica, za koga in zakaj? Za druge bralce, pripovedovalca o življenju ali za nas same? (Smith in Watson 2001: 12)

Neva Šlibar, ki se je v slovenski literarni vedi dolgoročno in ciljno posvečala značilnostim avtobiografskega pisanja, še posebej v zvezi z ženskimi avtoricami, vidi majhno razliko med funkcijo biografskega in avtobiografskega pisanja. Po njenih besedah

biografiki že zgodovinsko (z vzorčnim pripovedovanjem v življenjepisih in legendah) pripisujejo več etično-didaktičnega in faktografskega znanja, medtem ko je avtobiografika lahko močneje psihološko in socialno orientirana, nekako v obliki literature o življenjskih izkušnjah, ki jih je treba dojemati kot pomoč za življenje (Šlibar 1995: 392).

V zvezi s tradicionalnim pripisovanjem »objektivnega« biografiki in »subjektivnega« avtobiografiki Neva Šlibar utemeljeno opozarja, da se v obeh vrstah prepletata težnja po iskanju objektivnosti in subjektivne sodbe, in pravi:

Če posledično biografska besedila vsekakor kažejo 'avtobiografske' dele, velja enako obratno: Celo opisovanje samega sebe, ki je do skrajnosti osredotočeno na lastni jaz, kot na primer pet avtobiografskih knjig Thomasa Bernharda od Vzroka do En otrok, vsebuje predirljive portrete o sorodnikih, prijateljih in sovražnikih (Šlibar 1995: 393).

\section{Eksperimenti $z$ resnico $v$ nekaterih avtobiografskih delih}

Presoja vsake biografske oziroma avtobiografske literature se neizbežno povezuje z vprašanjem resnice oziroma razmerjem med dejstvi in fikcijo, toliko bolj, če se pisec sam obveže, da bo v svojem delu oblikoval »izvorno biografijo« in se predstavil kot pričevalec o dogodkih. ${ }^{5}$ Bistvene lastnosti avtobiografije so: večinoma je to pripoved v prozi, prikaz individualne življenjske zgodbe, poi-

\footnotetext{
${ }^{5}$ Podobno je pri zgodovinarju; zgodovinar ni »samo človek«, zgodovina pa ni samo preprosta »evolucija določenega procesa, temveč predvsem njegova epigeneza« (Luthar 2008: 179).
} 
stovetenje avtorja in glavnega junaka, značilna je retrospektivnost pripovedne perspektive (Wagner-Egelhaaf 2005: 1-6). Za avtobiografijo je najpomembnejše načelo, da se pisec čuti zavezanega resnici in si po najboljših močeh prizadeva za verodostojen prikaz dogodkov. ${ }^{6}$ Takšno aktualizacijo resnice osebne zgodovine opisuje Avrelij Avguštin v svoji avtobiografiji Izpovedi (Confessiones) 9, 18, ko pravi:

Ko prihodnost in preteklost bivata, bi rad vedel, kje sta. A tudi če mi to še ni dano, to pa vem: kjer koli že sta, nikjer nista kot prihodnost in preteklost, ampak kot sedanjost. Kajti če bi bila prihodnost tudi tam prihodnost, bi še ne bila tam, in če bi bila preteklost tudi tam preteklost, bi ne bila več tam. Kjer koli torej sta in kar koli že sta, ne moreta biti drugo kot sedanjost. Kadar pripovedujemo preteklo zvestó po resnici, dvigamo iz spomina ne mordà stvari same na dan, ki so prešlè, temveč le $\mathrm{v}$ besedah izražene podobe, ki so jih stvari nekoč, ko so prehajale mimo čutov, vtisnile v dušo. Tako je moja otroška doba, ki je ni več, pretekla v času, ki ga ni več: toda kadar se je spominjam in o njej govorim, gledam njeno podobo v sedanjem času, ker še zmerom biva v mojem spominu (Avguštin 1984: 257).

Presojanje resnice oziroma verodostojnosti pa ni samo vprašanje znanstvenega uma, temveč tudi zadeva ustvarjalnega duha. Vsebinske podrobnosti v avtobiografskem pisanju niso objektivno preverljive, kot tudi ni jasen vzrok za drobne vsebinske razlike; med možnimi vzroki za razlike sta lahko večja časovna oddaljenost in vloga spomina, mogoči pa so tudi kakšni drugi razlogi. Neva Šlibar tudi glede vidikov resnice dobro opredeljuje razliko med biografskim in avtobiografskim pisanjem. Če je biografsko pisanje bolj »naravno« v literarni formi, pa je avtobiografsko pisanje tako med bralci kot tudi v znanstvenih krogih veliko bolj zapaženo. Za to dejstvo najde tudi utemeljen razlog:

Vzroki za to preferenco ležijo v tem, da avtobiografska besedila veliko bolj neposredno kakor biografska ustrezajo stremljenju po avtentičnosti in neponarejeni življenjski izkušnji. /.../V estetskem pogledu so bolj stimulativna, ker omogočajo veliko bolj ustvarjalno obravnavo gradiva (Šlibar 1995: 394).

Med najbolj znanimi avtorji avtobiografskega pisanja od antike do novejše dobe so Avrelij Avguštin, Jean-Jacques Rousseau, Johann Wolfgang von Goethe, George Sand in Mohandas K. Gandhi. V zadnjih dveh stoletjih so avtobiografska dela ustvarili še številni drugi avtorji svetovne in slovenske književnosti. ${ }^{7}$ V Avguštinovih Izpovedih se prepletajo spomini in spoznanja

${ }^{6}$ Oto Luthar obravnava vire, ki po njegovem mnenju obstajajo samo kot del historične rekonstrukcije oziroma »spregovorijo« samo, ko so pravilno nagovorjeni. Meni, da je »vsaka prava interpretacija preteklosti zgolj pristranska, saj dejstva nikoli ne govorijo sama zase« (Luthar 2008: 178).

${ }^{7}$ Naj navedem nekaj avtorjev avtobiografij iz kroga literarnih ustvarjalcev. Veliko je nemških avtorjev: Gottfried Benn, Marcel Reich-Ranicki, Klaus Mann, Heinrich Böll, Theodor Fontane, Peter Härtling, Christa Wolf, Uwe idr. Med avstrijskimi pisatelji je npr. židovski pisatelj Elias Canetti. V angleščini je veliko avtobiografij iz Severne Amerike: politik in znanstvenik Benjamin Franklin, John Steinbeck, pisateljica Sylvia Plath, črnski pisatelj Booker T. Washington, Henry Miller; avtobiografije so pisali tudi ameriški 
o Bogu. Posebnost teh izpovedi je, da so pisane v obliki pogovora z Bogom, ki mu Avguštin izpoveduje svoje zmote iz mladostne dobe in pred katerim poveličuje novo življenje, ki se je začelo z obratom k njemu. Bog je zanj poosebljena resnica in ob tej resnici presoja vse drugo, kar je doživljal v svojem razgibanem življenju.

Jean-Jacques Rousseau je prevzel Avguštinov naslov za svojo izvirno avtobiografijo Izpovedi (Confessions) v dveh delih, pri katerem vsako obsega po šest knjig. Delo je končal leta 1769, a objavljeno je bilo šele po njegovi smrti, leta 1782. Njegove Izpovedi vsebujejo izrazito antropološko smer razmišljanja. Njegova izpoved se začenja z napovedjo:

Snujem delo, ki mu do sedaj še ni para in ki ne bo imelo posnemovalcev, ko bo končano. Svojim bližnjim hočem prikazati človeka v vsej njegovi resničnosti; in ta človek bom jaz (Rousseau 1955, zvezek 1: 9).

Pisatelj se obrača na bralce ter od njih pričakuje sočutje in razumevanje za svojo nevrednost in stiske; vedeti in čutiti jim da, da posebnosti njegovega značaja ni mogoče opisati. Pri tem mu gre za verodostojnost, ki jo tudi izrecno utemeljuje. Na koncu četrte knjige navaja svoje pogoje za dosego verodostojnosti:

$\mathrm{V}$ ta namen pa ne zadostuje, da je moje pripovedovanje zvesto, ampak mora biti tudi natančno. /.../ Ene same stvari pa se moram bati pri tem pisanju: ne tega, da bi povedal preveč ali da bi se lagal, ampak da bi ne povedal vsega in da bi zamolčal resnico (Rousseau 1955, zvezek 1: 256).

Kljub temu je očitno marsikaj zamolčal, saj šesto knjigo sklene s komentarjem:

Takšne so bile zablode in pregrehe moje mladosti. Njih zgodbo sem povedal s takšno vernostjo, da je je moje srce veselo. Če bi v nadaljnjem izkazal nekoliko časti svoji zreli dobi s kakšno čednostjo, bi jo zabeležil z isto prostodušnostjo, in takšen je bil tudi moj namen. Toda tukaj se moram ustaviti. Čas utegne odstreti marsikatero zaveso. Če se me bo potomstvo spominjalo, bo morda nekega dne izvedelo, kaj sem imel še povedati. Tedaj bo tudi vedelo, zakaj sem obmolknil (Rousseau 1956, zvezek 2: 75).

George Sand je svojo avtobiografijo Zgodba o mojem življenju (1855) napisala z bistveno drugačnim odnosom do življenjskih zgodb svojih znancev. Njeno osnovno vodilo je bilo ohranjanje zasebnosti, zato Rousseaujeve Izpovedi takole ocenjuje: »Na smrt trpim, ko vidim vélikega Rousseauja, kako se takole

indijanski pisatelj Natachee Scott Momaday, iz Avstralije Geoffrey Piers Henry Dutton, iz Anglije George Gordon Byron in William Somerset Maugham, iz Irske William Butler Yeats idr. Med francoskimi pisci avtobiografij sta pisatelja Edmond in Jules de Goncourt, pisateljica Amantine Aurore Lucile Dupin (George Sand), Jean d'Ormesson, André Gide idr. Avtobiografijo je napisal tudi danski pisatelj Hans Christian Andersen, pa ruski pisatelji: Vjačeslav Šiškov, Fjodor Mihajlovič Dostojevski, Maksim Gorki. Znana je pred kratkim prevedena avtobiografija Gabriela Garcíe Márqueza (Kolumbija) idr. Avtobiografije so pisali tudi številni avtorji s področij politike, znanosti, likovne umetnosti in drugi. 
ponižuje ... in se, vtem ko si morda celo izmišlja vse te grehe, razbremenjuje krivde za pregrehe srca, ki mu jih pripisujejo njegovi sovražniki« (Sand 2004: 297). Nancy K. Miller se navezuje na Sandovo v zvezi z njeno kritiko Rousseauja, ker ne upošteva zasebnosti oseb, ki jih vključuje v svojo avtobiografijo. Opozarja na etično odgovornost avtobiografov, ko poročajo o svojem življenju $\mathrm{v}$ intimnem odnosu $\mathrm{z}$ drugimi osebami, in priznava svojo stisko vesti v zvezi z njenim pisanjem, ko je z razkrivanjem resnice o odnosih do svojih staršev in drugih ljudi zagrešila »izdajstvo«. Izkušnja o prizadetosti oseb, ki so se znašle $\mathrm{v}$ avtobiografijah, ji narekuje spoznanje, kako zelo smo v življenjskih zgodbah pravzaprav vsi »ranljivi subjekti«. Sprašuje se, kako bi mogel avtobiograf pripovedovati zgodbo, ne da bi oskrunil osebne pravice drugih oseb:

Zvesto zapisano ali zlobno potvorjena, vaša zgodba kroži, popolnoma zunaj vašega nadzora. Je lahko takšna objava sploh kdaj poštena? Lahko etika sodeluje z močjo? Si lahko predstavljamo - si želimo - etiko izdajstva? Etično izdajstvo? ${ }^{8}$

Weimarski klasik Johann Wolfgang von Goethe je v letih od 1808 do 1831 napisal delo Iz mojega življenja. Pesnitev in resnica (Aus meinem Leben. Dichtung und Wahrheit). V tej svoji življenjski in umetniški izpovedi, v kateri je prišel le do petindvajsetega leta svojega življenja, je pisatelj spomin na svoje življenje vključil v univerzalno idejo o zgodovini, ki se razvija k nekemu cilju. Njegov poglavitni namen ni bil raziskovanje razmer, dela in dejanj osebnosti iz njegovega časa; hotel je ustvariti umetnino o svoji lastni zgodbi o uspehu in jo predstaviti kot model, ki bo vzgojno deloval na bralce. V svojem delu sporoča, da resničnega dejstva našega življenja ni mogoče zaznati ob spominu na pretekle dogodke, temveč z refleksijo o njihovem pomenu za življenje. Njegovo pisanje je poskus, da se iz odbranega življenjskega gradiva oziroma iz odlomkov iz življenja »dvignemo« do tistega »višjega«, neizrekljivega, ki nas približuje »višji resničnosti«. Goethe je v svojem pisanju ne samo natančen v analizi vzgibov svoje duše, ne le izjemno živ v odslikavanju takratnega časa, temveč tudi samoironičen, prav to pa njegovemu delu daje poseben šarm. Cilj njegove avtobiografije, ki se opira na konkretne dogodke iz njegovega življenja, je tisto najbolj resnično, ki v literarnem Goethejevem geniju postane simbol poetične resnice, to pa ustvarja napetost med ugotovitvami o doseženem in idejo o dosegljivem (Trunz 1998: 625-634).

Goethe je o "pesniški« in »fikcijski« resnici najbolj jasno spregovoril v obliki maksim in sentenc, posebno nazorno pa v obliki pogovora med odvetnikom umetnika in gledalcem z naslovom $O$ resnici in verjetnosti umetniških del (Über Wahrheit und Wahrscheinlichkeit der Kunstwerke). V tem pogovoru Goethe izpostavi »notranjo resnico«, ko odvetniku na usta polaga besede: »Prej smo operi odrekli neke vrste resnico; trdimo, da nikakor tega, kar posnema, ne predstavlja kot verjetno; a ji lahko zanikamo notranjo resnico, ki izvira iz doslednosti umetniškega dela? « Gledalec odgovarja: »Če je opera dobra, seveda

\footnotetext{
${ }^{8}$ Gl. The Ethics of Betrayal: Diary of a Conundrum. V: David Lazar, ur. Truth in Nonfiction, 47.
} 
zase naredi mali svet, v katerem se vse dogaja po določenih zakonih, ki presoja po svojih lastnih zakonih, hoče biti občuten po svojih lastnih lastnostih. « ${ }^{9}$

Mohandas K. Gandhi je leta 1925 končal svoje veliko avtobiografsko delo $\mathrm{z}$ naslovom Zgodba o mojih eksperimentih z resnico. V odgovor pomisleku svojemu prijatelju, da je pisanje avtobiografije posebnost Zahoda, na Vzhodu pa so pisali avtobiografska dela le tisti, ki so prišli pod zahodni vpliv, v uvodu daje razlago:

Vendar ni moj namen, da bi napisal pravo avtobiografijo; povedal bi rad samo zgodbo o svojih številnih eksperimentih z resnico, in ker moje življenje ni nič drugega kakor zbirka teh eksperimentov, bo res videti tako, kot da gre za pravo avtobiografijo (Gandhi 2010: 16).

Že v naslovu nakazuje, v uvodu pa izrecno poudarja, da je vse podrejeno iskanju resnice, tu pa daje tudi definicijo svojega razumevanja resnice:

Resnica je zame vrhovno načelo, ki vsebuje še mnoga druga. Ta resnica ni zgolj resnicoljubnost $\mathrm{v}$ besedi in misli in ne zgolj relativna resnica našega dojemanja, temveč absolutna resnica, večno načelo, se pravi Bog. /.../ Na tem popotovanju se mi je često odstiral bežen in medel vpogled $\mathrm{v}$ absolutno resnico, Boga, in vsak dan sem bil bolj prepričan, da je edinole on resničen, vse drugo pa neresnično (Gandhi 2010: 17).

V sklepnem zapisu Zbogom Gandhi znova izčrpneje razlaga svoje razumevanje resnice, in sicer v odnosu do samouresničevanja v življenju. Govori o potrebnosti samoočiščenja na vseh področjih življenja, zato se zaveda, da se mora osvoboditi strasti v mišljenju, govorjenju in dejanju. »Premagati pritajene strasti se zdi težje kakor z orožjem osvojiti snovni svet« (Gandhi 2010: 610).

\section{Cankarjevo sporočanje resnice v avtobiografiji Moje življenje}

Vprašanje avtentičnosti oziroma resničnosti v Cankarjevi avtobiografiji Moje življenje je bilo deležno pozornosti v članku Jožice Čeh »Med fikcijo in resničnostjo v avtobiografski prozi«. Avtorica obravnava razmerje med fikcijo in resničnostjo v literaturi na splošno in v odnosu do Cankarjevega dela. Skladno s tradicionalno literarno teorijo ugotavlja, da ločnico med literarnimi in neliterarnimi zvrstmi predstavlja prav meja med fikcijo in resničnostjo (Čeh 2008: 23). Glede vidikov resničnosti, ki so temeljni v številnih delih Ivana Cankarja, je zanimiva študija H. Porterja Abbotta; v navajanju mnenj o razliki med žanri, ki se opirajo na dejanske dogodke, in fikcijo, opozarja na dejstvo, da tudi pisatelji, ki se opirajo na zgodovinske dogodke, te navajajo selektivno glede na njihov pomen in si pri tem $v$ navajanju dogodkov dovolijo različne vrzeli. Bralec v literarnih delih išče bolj resnico pomena kakor fakta po svoji lastni izkušnji realnosti. Delo ne bo prepričljivo, če je zgodba na primer »predobra,

${ }^{9}$ Gl. Goethes Werke, Band XII. Uredila Erich Tunz in Joachim Schrimpf. München: C.

H. Beck, 1998, 67-73, citat na str. 70. 
da bi bila resnična«, še manj, če je zgodba napačna. Prav na pomen tovrstnega presojanja resnice opozarja Ivan Cankar na koncu svojega dela Moje življenje, ko po branju Rousseaujevih Izpovedi ugotavlja:

Naprtil je svoji ubogi mladosti toliko različnih grehov, kolikor si jih je le mogel izmisliti, nazadnje pa je vse te grehe z globoko učenostjo razložil in opravičil. Ob njegovih samoizpovedih obide človeka tisti občutek, ki je za pisatelja najstrašnejša obsodba: ne verjame mu (Cankar 1975: 50).

Cankarjev posluh za vprašanje resničnosti oziroma resnice se kaže tudi v njegovi oceni samoizpovedi Janeza Trdine. Njegove izpovedi v Mojem življenju pohvali: »Brezobzirno pravičen je bil do sebe, usmiljeno pravičen do drugih ljudi.« Kljub temu presodi, da podoba njegove mladosti ni čisto resnična, ker pisatelj »nikoli ne more zatajiti starokopitnega šolmaštra« (Cankar 1975: 50). Cankar poudari svoje razloge, zaradi katerih dvomi o verodostojnosti avtobiografskega pisanja: le-to se namreč v svojih poizkusih zmore le bolj ali manj približati »celotni«, »končni« resnici. Meni, da so nasprotja navzoča že v človekovi eksistenci, v nasprotju med njegovim iskanjem in begom; prav zaradi teh nasprotij bo človekova samopodoba po njegovem prepričanju »presvetla ali bo pretemna, resnična ne bo in nikoli ne more biti«.

Človekova intimna razklanost povzroči tudi neskladnost v njegovi samoizpovedi, kot pravi Cankar: »Umetnik je tisti otrok, ki poje v gozdu, da bi ne skoprnel od strahu. Ne išče se - ušel bi si rad.« In sklene:

Če hočeš biti tako odkritosrčen, da bi ne povesil oči pred samim Bogom, boš pisal do groba zgodovino tistega enega dne. In razodel boš tolike strahote, da bodo ljudje najprej tebe kamenjali, nato pa drug drugega. In če bo kateri ostal, bo od prevelike radosti skoprnel ob nezaslišanih lepotah, ki si mu jih bil razodel (Cankar 1975: 51-52).

Cankarjevo razglabljanje spominja na razlago odgovornosti do resnice, ki jo daje pisatelj in profesor Mark Doty z Univerze v Houstonu v svojem prispevku za knjigo Truth in Nonfiction. Verjame, da si pesniki in pisatelji življenjskih zgodb prizadevajo za resnico. Ne gre jim za to, kar se je zgodilo, temveč za izkušnjo o tem, kar se je zgodilo:

Povedati želim, da onkraj osebne etike spomina - kako pošteni ali nepošteni smo do drugih ljudi v svojem življenju - in onkraj vprašanja točnosti obstaja višji etični standard, ki ima opraviti z etiko umetnosti: da je to, kar se ustvari, sorazmerno z resničnim (Lazar 2008: 14).

Cankar v resničnem življenju doživlja nespravljivost nasprotij in se sprašuje: »Čemu še življenjepis?« (Cankar 1975: 51). Toda kljub sodbi nekaterih, da si umetnik piše »nekrolog«, in mnenjem drugih, da si poje »slavo še ob živem telesu«, meni, da je življenjepis smiselno pisati: »Nikakor ne zato, da bi se razkazoval po vlačugarsko, tudi zato ne, da bi pisal povesti ljudem v pouk in zabavo, temveč edinole, da se razgleda sam po prostranih poljanah svoje duše, da sega mukoma in trepetoma iz prepada v prepad svojega bitja, da išče dna« (Cankar 1975: 52). Cankar resnico presoja predvsem s kriteriji etike, kot med drugim zapiše v Beli krizantemi (1910): 
Ponos je v mojem srcu; kljub vsem naukom, opominom, očitkom, kljub zasmehu, zmerjanju in natolcevanju je vse moje življenje in nehanje služilo najvišji ideji: resnici! Kar sem videl z očmi, s srcem in z razumom, nisem zatajil; in bi ne bil zatajil za same zlate nebeške zvezde. Resnica pa je posoda vsega drugega: lepote, svobode, večnega življenja (Cankar 1975: 267).

Ta Cankarjeva zavezanost resnici razloži lepoto in sugestivnost njegovega pisanja. David Shields v svojem prispevku »Reality, Persona« za knjigo Truth in Nonfiction (Lazar 2008: 77-88) zapiše nekaj izrekov, ki izražajo resničnost v tem univerzalnem smislu: »Vse najboljše zgodbe so resnične«; »Človekovo življenje, ki je kaj vredno, je neprekinjena alegorija«; »Kar je resnično zate v tvojem privatnem srcu, je resnično za vse ljudi«; »Vsak človek ima v sebi celotno stanje človeštva.«

Cankarjevo delo Moje življenje je dragocen zgled izvirne literarne stvaritve, ki vsebuje še posebej veliko avtobiografskih prvin glede na njegov celotni literarni opus. ${ }^{10}$ Pisatelj v štirinajstih črticah opisuje doživljaje in podobe iz svoje mladosti. V njegovih spominih, v katerih se vrača v obdobja od zgodnjih otroških let do dijaških let v Ljubljani in do prvih študentskih let na Dunaju, je še posebej izrazita podoba njegove matere. V Cankarjevih

prvoosebnih črticah je ubeseden eden ali več drobnih dogodkov iz otroštva, tako da je v ospredju pripovedovalčevo etično vrednotenje teh dogodkov. Črtice so razvrščene tako, da si posamezni dogodki iz otroštva sledijo $\mathrm{v}$ časovnem zaporedju, obenem posamezno besedilo deluje kot samostojna enota, ki jo lahko beremo tudi ločeno od preostalih delov, zato je Cankarjevo Moje življenje smiselno pojmovati kot cikel avtobiografskih črtic (Čeh 2008: 29).

Jožica Čeh ugotavlja, da se v Cankarjevi avtobiografiji »kot pomembni besedilni fikcijski signali pokažejo avtocitatnost, avtotematskost, lirsko meditativni tip črtice, značilna simbolika, metaforika idr.« (Čeh 2008: 31).

Marko Juvan z naslovom svojega prispevka »Avtobiografija in kočljivost zvrstnih opredelitev: Moje življenje med tekstom in žanrom« jasno nakaže težišče svoje študije o Cankarjevi avtobiografiji. Primerjava Cankarjevega dela z Avguštinovimi in Rousseaujevimi Izpovedmi, delno pa tudi s Trdinovim Mojim življenjem, ga vodi do sklepa, da je Cankarjevo besedilo

eden od odličnih primerov, kako avtobiografija izpada iz žanrskih klasifikacij diskurzov (literarni - neliterarni, zasebni - javni itn.) in v njih nedoločljivo kroži kot zvrstna monada sui generis (Juvan 2009: 319).

V zadnji črtici Mojega življenja Cankar v zvezi s svojim pogledom na avtobiografsko pisanje izpostavi antitezo otrok // starec ter poudarja, da sta si njuni sodbi o modrosti v nasprotju (Cankar 1975: 49). S tem nasprotjem obenem razkrije merilo za presojo verodostojnosti avtobiografskega pisanja:

${ }^{10}$ Črtice iz tega cikla je Cankar začel pisati poleti ali vsaj v začetku jeseni leta 1913, izhajale so v reviji Slovenski narod do srede leta 1914, v knjižni obliki pa so bile objavljene šele leta 1920. (Janko Kos v: Cankar 1975: 275). 
to je etično merilo otroške čistosti in iskrenosti. O tem pravi: »Spoštovanje ne prenese nobene laži, ne zavijanja, še pretiravanja ne. Najhujše je, da tudi ne prenese prikrivanja« (Cankar 1975: 49). Po tem načelu Cankar presoja tudi verodostojnost Rousseaujevih Izpovedi (Cankar 1975: 50).

\section{Sklep}

Namen pisanja avtobiografije so nekateri pisatelji sami označili. Rousseau na začetku svojih avtobiografskih Izpovedi pravi, da hoče prikazati človeka v vsej njegovi resničnosti - »in ta človek bom jaz«. Goethe je svoje življenje predstavil kot največje umetniško delo, ki vsaj toliko kot »zunanjo« odraža »notranjo« resnico, Ivan Cankar v Mojem življenju resnico o svojem življenju v ožjem in širšem življenjskem kontekstu doživlja in opisuje kontrastno pod različnimi vidiki. Gandhi svojo avtobiografijo imenuje »eksperiment z resnico«. Pisci avtobiografije prikazujejo različne vidike vsebinske in estetske resničnosti. $\mathrm{Ob}$ poizkusih, da bi čim jasneje prikazali življenjsko resničnost in resnico, navadno bolj ali manj izrecno izrekajo tudi svoje poglede na resnico $\mathrm{v}$ življenju in $\mathrm{v}$ literarnem besedilu.

Pojma resničnosti in resnice se pojavljata pod različnimi vidiki dokaj nedoločeno, vendar vsakokratni kontekst nakazuje vidik, ki ga ima pisatelj v mislih. Pesniki in pisatelji pojme uporabljajo v celotnem razponu možnih pomenov, saj je ravno za literaturo značilno, da je ožji in širši kontekst osnovno merilo določitve pomenskih vidikov rabe besed. Zato je razumljivo, da osnovni namen posameznih literarnih vrst in zvrsti bistveno določa pomenski vidik v rabi besed resničnosti in resnice.

\section{VIRI IN LITERATURA}

H. Porter ABBOT, 2. izd. 2008, šesti natis 2010: The Cambridge Introduction to Narrative. Druga izdaja. Cambridge: Cambridge University Press. Zlasti poglavje 11: Narrative and Truth (145-159).

ARISTOTELES, 2005: Poetika. Prevedel, uvod in opombe napisal Kajetan Gantar. Ljubljana: Študentska založba. (Knjižna zbirka Claritas, 39).

Erich AUERBACH, 8. izdaja 1988: Mimesis: Dargestellte Wirklichkeit in der abendländischen Literatur. Bern / Stuttgart: Francke V slovenščino prevedel in spremno besedo napisal Vid Snoj, 1998: Mimesis: Prikazana resničnost v zahodni literaturi. Ljubljana: Literarno-umetniško društvo Literatura. (Zbirka Labirinti).

Avrelij AVGUŠTIN, 1984: Izpovedi. Prevedel Anton Sovre, priredil Kajetan Gantar. Celje: Mohorjeva družba.

France BERNIK, 1988: Avtobiografsko v novejši slovenski vojni prozi. Tipologija pripovednih položajev. Sodobni slovenski jezik, književnost in kultura. Mednarodni 
simpozij v Ljubljani od 1. do 3. julija 1986. Ur. Boris Paternu in Franc Jakopin s sodelovanjem Petra Weissa. Ljubljana: Filozofska fakulteta. (Zbornik Obdobja, 8). $145-149$.

Ivan CANKAR, 1975: Zbrano delo, zvezek 22. Gl. ur. Anton Ocvirk. Knjigo pripravil in opombe napisal Janko Kos. Ljubljana: Državna založba Slovenije.

--, 1975: Zbrano delo, zvezek 24: Bela krizantema. Opombe napisal Dušan Voglar. Ljubljana: Državna založba Slovenije.

Jožica ČEH, 2008: Med fikcijo in resničnostjo v avtobiografski prozi. Jezik in slovstvo 53/3-4, 23-36.

Mohandas K. GANDHI, 2010: Avtobiografija: Zgodba o moji eksperimentih z resnico. Prev. Uroš Kalčič, spremno besedo napisal Andrej Ule. Ljubljana: Modrijan.

Johann Wolfgang von GOETHE, 1998: Goethes Werke, zvezki 9-11: Autobiographische Schriften. München: C. H. Beck.

- -, 2007: Poezija in resnično. Iz mojega življenja. Izbral, prevedel in spremno besedo napisal Štefan Vevar. Ljubljana: Študentska založba. (Zbirka Claritas, 46).

Igor GRDINA, 2003: Poti v zgodovino. Ljubljana: Založba ZRC.

- -, 1994: Avtobiografska književnost pri Slovencih v dvajsetem stoletju: doktorska disertacija. Ljubljana: [Igor Grdina].

Käte HAMBURGER, 2004: Resnica in estetska resnica. Prevedel Tomo Virk. Ljubljana: Literarno-umetniško društvo Literatura. (Labirinti).

Walter HIRSCH, 1995: Platon in problem resnice. Prevedel Aleš Košar. Phainomena 4/13-14, 20-48.

Miran HLADNIK, 2009: Slovenski zgodovinski roman. Ljubljana: Filozofska fakulteta.

Marko JUVAN, 2009: Avtobiografija in kočljivost zvrstnih opredelitev: Moje življenje med tekstom in žanrom. Slavistična revija 57/2, 311-320.

David LAZAR, ur., 2008: Truth in Nonfiction: Essays. Iowa City: University of Iowa Press.

Vincent B. LEITCH (ur.), 2010: The Norton Anthology of Theory and Criticism. New York / London: W. W. Norton \& Company.

Philippe LEJEUNE, 2005: Signes de vie. Le pacte autobiographique 2. Paris: Éditions du Seuil.

Oto LUTHAR in Breda LUTHAR, 2007: Trio za orkester: Resničnost, pripoved in pomen. Filozofski vestnik 28/1, 103-119.

- -, 2008: Zapoznela budnica ali resnični začetek konca sanj o objektivni zgodovini? (Spremna beseda). Kaj je zgodovina? Avtor Edward Hallet Carr, prevod Tomaž Jurca. Ljubljana: Studia humanitatis. 169-189.

PLATON, 1995: Država. Prevedel Jože Košar, spremno besedo napisal Valentin Kalan. Ljubljana: Mihelač. (Zbirka Svetovni klasiki, 40). Opombe Jožeta Košarja (325-411). 
Jean-Jacques, ROUSSEAU, 1955-1956: Izpovedi, zvezki 1-3. Prev. Silvester Škerl. Ljubljana: Slovenska matica.

George SAND, 2004: Zgodovina mojega življenja. Prevedla Radojka Vrančič. Ljubljana: Delta, društvo za kulturološke raziskave. (Delta: knjižna zbirka za ženske študije in feministično teorijo).

Philip SIDNEY, 2010: The Defence of Poetry. V: Vincent B. LEITCH (ur.), The Norton Anthology of Theory and Criticism. New York/London: W. W. Norton \& Company. 251-283.

James SMALLWOOD, 1995: Truth. International Encyclopedia of Ethics. Ur. John K. Roth. London, Chicago: Fitzroy Dearborn Publishers. 883-886.

Sidonie SMITH in Julia WATSON, 2001: Reading Autobiography. A Guide for Interpreting Life Narratives. Minneapolis / London: University of Minnesota Press.

Neva ŠLIBAR, 1995: Biographie Autobiographie. Annäherungen, Abgrenzungen. Geschriebenes Leben. Autobiographik von Frauen. Ur. Michaela Holdenried. Berlin: E. Schmidt. 390-401.

- -, 1996: Ženski (avto)biografski diskurz: O njegovi subverzivnosti in potrebi po uzaveščanju njegovih pravil. Delta: Revija za ženske študije in feministično teorijo 2/1-2, 65-77.

- -, 2009: Literarna dela in avtobiografski spisi Alme M. Karlin: Tematiziranje obdobja 1940-1945. Almine meje in margine. Ur. Marija Počivavšek. Celje: Muzej novejše zgodovine Celje. 44-61.

Miran ŠTUHEC, 2008: Slovenska esejistika v presečišču biografskih in avtobiografskih vidikov. Jezik in slovstvo 53/3-4, 89-100.

Lev Nikolajevič TOLSTOJ, 1980: O umetnosti in družbi. Prevedla Janko Moder in Josip Vidmar. Ljubljana: Državna založba Slovenije.

Janez TRDINA, 1998: Moje življenje. Aron in Zman, Pripovedka od Glasan-Boga, Verske bajke (izbor), Bajke in povesti o Gorjancih (izbor), Moje življenje. Besedila pripravil in spremno besedo napisal Iztok Ilich. Ljubljana: DZS. (Zbirka Slovenska klasika).

Martina WAGNER-EGELHAAF, 2. izdaja 2005: Autobiographie. Stuttgart: J. B. Metzlersche Verlagsbuchhandlung.

\section{TRUTH IN AUTOBIOGRAPHY}

Representation of Reality in some Historic Autobiographies and in Ivan Cankar's Moje življenje ('My Life')

This article focuses on some of the inherent foundations of perceiving and expressing truth in autobiography, in comparison with the art of poetry and fiction, and compares relevant statements in classic autobiographies and Ivan Cankar's autobiography Moje življenje / My Life about his perception of truth. This work presents Cankar's originality in such a way that the generally important things and life's reality, with all its inherent 
tensions, are revealed. Any attempt to assess the content, truth, originality and style of an autobiography presupposes knowledge of the general characteristics of autobiographical writing, especially when compared to various forms of biography. The basic question when judging the quality and value of autobiographical works is the criterion of truth. The life circumstances and feelings of the author are hardly singular in a strict sense. Ivan Cankar asks in Moje življene / My Life, in connection with his own experience: "Who is this? Is it really me? Is it not my poor George ...?" The interaction between historical fact and inner life is beyond the reach of our perception and description. Autobiographies, however, appeal wholly to observation and the experience of the value of moral truth. Virtue is the highest proof of understanding, and sincerity the only solid basis of greatness. Autobiographies reflect the mind that can only repose on the stability of truth. 